
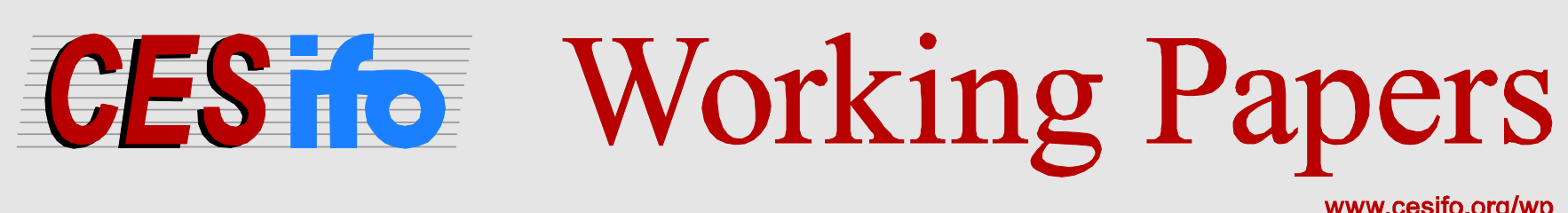

www.cesifo.org/wp

\title{
Long-Term Interest Rates and Public Debt Maturity
}

\author{
Ieva Sakalauskaite \\ Roel Beetsma \\ Massimo Giuliodori
}

\section{CESIFO WORKING PAPER NO. 4408 \\ CATEgory 6: Fiscal Policy, Macroeconomics and Growth \\ SEPTEMBER 2013}

An electronic version of the paper may be downloaded

- from the SSRN website:

www.SSRN.com

- from the RePEc website:

- from the CESifo website:

www.RePEc.org

www.CESifo-group.org/wp

\section{CESifo}




\title{
Long-Term Interest Rates and Public Debt Maturity
}

\begin{abstract}
For a sample of sixteen OECD countries over the period 1980-2007 we show that, for given debt-GDP ratio, an increase in the maturity of the public debt by one year lowers its long-term interest rate by around 20-30 basis points. This effect is stronger for countries with higher average inflation or debt.
\end{abstract}

JEL-Code: E430, E440, H620, H630, H680.

Keywords: debt, maturity, long-term interest rates, inflation, OECD.

Ieva Sakalauskaite

University of Amsterdam \&

Tinbergen Institute

The Netherlands ievasakalauskaite@hotmail.com
Roel Beetsma*

MN Chair in Pension Economics

University of Amsterdam \&

Tinbergen Institute

The Netherlands

r.m.w.j.beetsma@uva.nl

Massimo Giuliodori

University of Amsterdam \&

Tinbergen Insitute

The Netherlands

m.giuliodori@uva.nl

*corresponding author

We thank Eric Bartelsman and Franc Klaassen for helpful comments. 


\section{Introduction}

In recent years a number of contributions have explored the empirical relationship between long-term interest rates and fiscal indicators, in particular the public deficit and the public debt (see, for example, Ardagna et al., 2007, and Aisen and Hauner, 2013). There appears to be some consensus that better fiscal indicators go together with lower interest rates, although the estimated strength of the relationships differs across studies.

In this paper, we explore how the maturity of the public debt affects the abovementioned relationship between fiscal indicators and long-term interest rates. Our findings can help in answering the interesting question what will happen to interest rates when for a given debt level the government manages to lengthen the maturity of its outstanding stock of debt. ${ }^{3}$ For a sample of sixteen OECD countries over the period 19802007, we find that holding constant the debt-GDP ratio, an increase in the average maturity of the public debt leads to a reduction in the long-term interest rate. We establish this result first in a static set-up that introduces maturity into the empirical model of Ardagna et al. (2007) and then in a panel vector auto-regression (PVAR) framework. Moreover, we establish that the maturity effect is only present for countries that have on average relatively high inflation or high debt. Apparently, the ability of these countries to issue longer debt boosts financial market confidence that the outstanding debt is sustainable.

The remainder of this paper is structured as follows. Section 2 introduces our baseline static empirical specification and describes our dataset. Section 3 discusses our baseline estimates, while Section 4 presents the PVAR specification and reports impulse responses for maturity shocks. Finally, Section 5 concludes.

\section{Baseline specification and data}

Our baseline specification is static. Later, we turn to the estimation of dynamic models. In the spirit of Ardagna et al. (2007) we estimate models of the format: ${ }^{4}$

\footnotetext{
${ }^{3}$ Of course, the government should have some margin of freedom to change the maturity. For example, lack of confidence in monetary policy can force the government to shorten the maturity (Missale and Blanchard, 1994).

${ }^{4}$ Panel unit root tests based on Im et al. (2003) show that the unit root hypothesis can be (strongly) rejected for most variables. For the debt-to-GDP ratio and the maturity the tests are only close to $10 \%$ significance. This is likely to be the result of these variables being only slowly moving. Since it is hard to economically justify unit roots for these variables, we continue with our current specification.
} 


$$
L R I_{i t}=\lambda_{i}+\mu_{t}+\alpha \text { FISCAL }_{i t}+\beta \text { MATURITY }_{i t}+\gamma \text { CONTROLS }_{i t}+\varepsilon_{i t},
$$

on a panel running over countries and years where $\lambda_{i}$ is a country-fixed effect, $\mu_{t}$ is a yearfixed effect, $L R I_{i t}$ is the average long-term (in most cases, 10-year) government debt yield for country $i$ in year $t$, FISCAL $L_{i t}$ captures fiscal indicators (in particular, the lag of the debt-toGDP ratio, $D E B T_{i, t-1}$, and the primary surplus-to-GDP ratio, PSURPLUS $S_{i t}$ ), MATURITY ${ }_{i t}$ is the average residual length of central government commitments (in years), and CONTROLS $S_{i t}$ is a set of variables to control for the business cycle and monetary policy. ${ }^{5}$ It contains consumer price inflation $I N F L_{i t}$, real GDP growth GROWTH $H_{i t}$ and the short-term (90-day or 3-month) nominal interest rate $S R I_{i t}$. We include country-fixed effects to control for timeinvariant country-specific factors such as the history of public debt defaults, the quality of public institutions and the liquidity of the markets, all of which might have an effect on a country's long interest rate. We also allow for year-fixed effects to control for global shocks that simultaneously affect all public debt markets and to account for the general downward trend in long-term interest rates over our sample period. The important new element of (1) is the inclusion of the maturity variable.

We use annual data for sixteen OECD countries over the period 1980-2007. ${ }^{6}$ These countries are Australia, Austria, Belgium, Canada, Denmark, France, Germany, Ireland, Italy, Japan, the Netherlands, New Zealand, Spain, Sweden, the U.K. and the U.S. Table 1 reports some basic statistics of our data. In particular, it indicates substantial variation in all our variables of interest.

Table 1: Basic statistics

\begin{tabular}{|l|c|c|c|c|c|}
\hline Variable & Obs & Mean & St.dev. & Min & Max \\
\hline LRI & 448 & 8.06 & 3.76 & 1.00 & 20.5 \\
\hline SRI & 440 & 7.44 & 4.52 & 0.05 & 23.3 \\
\hline PSURPLUS & 442 & 1.21 & 3.27 & -11.6 & 11.6 \\
\hline DEBT & 447 & 63.0 & 28.6 & 9.71 & 175 \\
\hline INFL & 448 & 4.00 & 3.71 & -0.90 & 21.1 \\
\hline GROWTH & 448 & 2.65 & 1.88 & -2.86 & 10.9 \\
\hline
\end{tabular}

\footnotetext{
${ }^{5}$ We obtain most of our data from the online database and central government debt publications of the OECD. Data on debt and deficits are for the general government, while data on maturity are only available for the central government. For Japan and Sweden we only have the average maturity of total, rather than marketable, liabilities, while for Belgium our maturity data were obtained from the ECB database. We considered various potential alternative sources of maturity data, but found that they were either more limited in the time or in the cross-sectional dimension.

${ }^{6}$ We choose to end our sample period in 2007 to avoid any potentially disturbing effects of the recent economic and financial crisis.
} 


$$
\text { MATURITY }
$$

5.33

1.80

0.83

Notes: “Obs" is number of observations and "St.dev." is standard deviation. LRI, SRI, INFL and GROWTH are in per cent per year, PSURPLUS and DEBT are in per cent of GDP, and MATURITY is in years.

\section{Results for the baseline specification}

Table 2 reports the estimates for various specifications of equation (1). All estimates are obtained through OLS. Column (1) reports estimates for the case in which the maturity is not included in the regression. The effects of the fiscal indicators are qualitatively as expected. An increase in the primary surplus by one percentage point reduces the long-term interest rate by 7 basis points, while an increase in the lagged debt ratio raises the long-term interest rate by 0.7 basis points. An increase in the short-term interest rate by one percentage point raises the long-term interest rate by 0.4 percentage point. The positive relationship between long and short rates is in line with the tendency of the entire yield curve to exhibit vertical shifts in response to shocks. A one-percentage point increase in real GDP growth raises the long rate by almost 7 basis points, presumably because higher growth forebodes higher inflation. Finally, a one percentage-point rise in inflation pushes the long rate up by 23 basis points. Column (2) adds the current average maturity to regression. While the coefficient estimates of the controls and the primary surplus are essentially unaffected, the coefficient on the lagged debt ratio shrinks in size and loses its significance. Apparently, the debt ratio is wiped out by the presence of the maturity, which enters with a negative coefficient that is significant at the $10 \%$ level. Feedback effects from the dependent variable to the explanatory variables are unlikely: the primary surplus does not include interest expenditure, while the short interest rate is to a large extent under the control of the monetary authorities. To the extent that long interest rates feedback on economic activity and inflation one would expect this to happen with a lag mainly through investments and durable expenditures. It is conceivable that the authorities decide to react to a change in the long interest rate with a change in maturity. However, Column (3), which includes the lagged average maturity suggests that such effects are unimportant. The magnitude of the lagged maturity is even slightly stronger and its significance has increased. We have also conducted some robustness analyses, one in which we replaced the year-fixed effects with linear and quadratic time trends and another in which we included projections of fiscal variables. Further, we did rolling regressions with a fifteenyear window. The results were always qualitatively quite similar and are not discussed further. 
We now consider the effects of maturity for two cross-sectional sample splits. In one we split the set of countries into a groups with below- and above-median inflation over our sample period. ${ }^{7}$ We introduce a dummy $D H I N F L_{i}$ that is one (zero) for countries in the latter (former) group. ${ }^{8}$ Similarly, we split our countries into a group with a below- and abovemedian debt ratio by introducing a dummy $\mathrm{DHDEBT}_{i}$ that is one (zero) for countries in the latter (former) group. ${ }^{9}$ Column (4) reports the estimates for the split into low and highinflation countries. The coefficients of the controls and the fiscal indicators are hardly affected. Importantly, the results show a clear difference of the effect of an increase in maturity for the two country groups. While we do not detect an effect for the low inflation group, we see a clear and significant negative effect of an increase in maturity on long interest rates for the high-inflation group. Based on the sum of the coefficients on MATURITY $_{i, t-1}$ and MATURITY Mit-1 $^{*}$ DHINFL $_{i}$, we see that a one-year increase in average maturity lowers the long-term interest rate by more than 30 basis points. Column (5) reports the estimates for the split into low and high-debt countries. Again the coefficients of the controls and the fiscal indicators are hardly affected. An increase in average maturity has a significant positive effect for the low-debt group, while it has a highly significant negative effect for the high-debt group. For the latter group, a one-year increase in average maturity lowers the long-term interest rate by 32 basis points, about double the positive effect for the low-debt countries.

Table 2: Estimates for various specifications of equation (1)

\begin{tabular}{|c|c|c|c|c|c|}
\hline & \multicolumn{5}{|c|}{ Dependent variable: $L R I_{i t}$} \\
\hline & (1) & (2) & (3) & (4) & (5) \\
\hline PSURPLUS $_{i t}$ & $\begin{array}{l}-0.0705^{* *} \\
(0.0265)\end{array}$ & $\begin{array}{c}-0.0677^{* *} \\
(0.0285)\end{array}$ & $\begin{array}{l}-0.0636^{* *} \\
(0.0301)\end{array}$ & $\begin{array}{l}-0.0553^{*} \\
(0.0295)\end{array}$ & $\begin{array}{l}-0.0519^{*} \\
(0.0270)\end{array}$ \\
\hline$D E B T_{i, t-1}$ & $\begin{array}{l}0.00716^{* *} \\
(0.00262)\end{array}$ & $\begin{array}{c}0.00281 \\
(0.00242)\end{array}$ & $\begin{array}{c}0.00177 \\
(0.00279)\end{array}$ & $\begin{array}{c}0.00414 \\
(0.00334)\end{array}$ & $\begin{array}{l}-0.00090 \\
(0.00285)\end{array}$ \\
\hline MATURITY $_{i t}$ & & $\begin{array}{l}-0.186^{*} \\
(0.101)\end{array}$ & & & \\
\hline MATURITY $_{i, t-1}$ & & & $\begin{array}{l}-0.196^{* *} \\
(0.0817)\end{array}$ & $\begin{array}{c}0.106 \\
(0.0846)\end{array}$ & $\begin{array}{l}0.157^{* *} \\
(0.0791)\end{array}$ \\
\hline $\begin{array}{l}\text { MATURITY }_{i, t-1 *} \\
\text { DHINFL }_{i}\end{array}$ & & & & $\begin{array}{l}-0.413^{* * * *} \\
(0.113)\end{array}$ & \\
\hline
\end{tabular}

\footnotetext{
${ }^{7}$ As an alternative we considered a split based on inflation data over the period 1970-1979. This did not affect our results (see Appendix - not for publication).

${ }^{8}$ The above-median inflation group consists of Australia, Ireland, Italy, New Zealand, Spain, Sweden, United Kingdom and the United States.

${ }^{9}$ The above-median debt countries are Belgium, Canada, Denmark, Ireland, Italy, Japan, the Netherlands, United States.
} 


\begin{tabular}{|c|c|c|c|c|c|}
\hline $\begin{array}{l}\text { MATURITY }_{i, t-1 *} \\
\text { DHDEBT }_{i}\end{array}$ & & & & & $\begin{array}{l}-0.473^{* * *} \\
(0.112)\end{array}$ \\
\hline$S R I_{i t}$ & $\begin{array}{l}0.416^{* * *} \\
(0.0369)\end{array}$ & $\begin{array}{l}0.400^{* * *} \\
(0.0370)\end{array}$ & $\begin{array}{l}0.412^{* * *} \\
(0.0409)\end{array}$ & $\begin{array}{l}0.389^{* * * *} \\
(0.0363)\end{array}$ & $\begin{array}{l}0.377^{* * *} \\
(0.0374)\end{array}$ \\
\hline GROWTH $_{\text {it }}$ & $\begin{array}{l}0.0651^{* *} \\
(0.0262)\end{array}$ & $\begin{array}{l}0.0725^{* *} \\
(0.0356)\end{array}$ & $\begin{array}{l}0.0796^{* *} \\
(0.0388)\end{array}$ & $\begin{array}{l}0.0665^{* *} \\
(0.0306)\end{array}$ & $\begin{array}{l}0.0709^{* *} \\
(0.0302)\end{array}$ \\
\hline$I N F L_{i t}$ & $\begin{array}{l}0.233^{* * * *} \\
(0.0368)\end{array}$ & $\begin{array}{l}0.192^{* * * *} \\
(0.0459)\end{array}$ & $\begin{array}{l}0.179^{* * *} \\
(0.0439)\end{array}$ & $\begin{array}{l}0.167^{* * *} \\
(0.0369)\end{array}$ & $\begin{array}{l}0.176^{* * *} \\
(0.0350)\end{array}$ \\
\hline Adjusted $\mathrm{R}^{2}$ & 0.961 & 0.967 & 0.966 & 0.969 & 0.969 \\
\hline$N$ & 420 & 317 & 305 & 305 & 305 \\
\hline
\end{tabular}

Notes: (i) All estimates are obtained through OLS. (ii) Robust standard errors are reported in parentheses. (iii) $N$ $=$ number of observations. 


\section{Dynamic analysis}

We now explore the dynamic effects of a change in maturity using a panel VAR with as vector of endogenous variables [PSURPLUS ${ }_{i t}, D E B T_{i t}$, MATURITY $\left._{i t}, L R I_{i t}\right]$ '. ${ }^{10}$ Based on this specific ordering of the endogenous variables we obtain identification through a Cholesky (lower-triangular) decomposition. We choose this ordering because on the one hand we do not expect the maturity of the debt to have a primary role in the government's decisions about its revenues, expenditures and debt ratio, while on the other hand the debt maturity might be affected by new debt issues associated with the financing of budget deficits or a change in the stock of debt. Being a financial variable that can react almost instantaneously, we order $L R I_{i t}$ last. The PVAR also includes country- and year-fixed effects. As suggested by the Schwartz information criterion, we allow for two lags in the PVAR.

Figure 1 depicts the impulse responses, together with a confidence band of \pm 1.645 standard deviations around the central line, to a one-year maturity increase. Hence, we consider a $10 \%$ significance level for deviations from zero. The surplus and the debt ratio do not reveal any significant reaction, while the long-term interest rate exhibits a significant downward jump of roughly 3 basis points on impact, after which it slowly moves back to its original level. For our cross-sectional splits, we only show the responses of the long-term interest rate to the maturity shock, which is always set to one year. These are depicted in Figure 2. In line with our findings for the static model, in the case of a split into low- and high inflation countries a positive maturity shock does not significantly affect the long-term interest rate for the low-inflation countries, while it has a significant negative impact effect for the high-inflation countries. Similarly, for the split into low- and high-debt countries it has a significant negative impact on the long-term interest rate for the high-debt countries and no effect for the low-debt countries. Compared with the full sample the impact effects for the high-inflation and high-debt countries are stronger at roughly 4 and 5 basis points, respectively. The results of our panel VAR analysis are qualitatively in line with the results of our static analysis, although the magnitude of the effects of a given maturity increase has become weaker.

\footnotetext{
${ }^{10}$ Because of the limited sizes of the sub-samples we have chosen to be parsimonious. Similar, but, due to the over parameterization of the VAR, weaker results are obtained if we add $S R I_{i t}, G R O W T H_{i t}$ and $I N F L_{t}$ to our set of endogenous variables.
} 
Figure 1: Responses to a one-year maturity increase

Primary Surplus
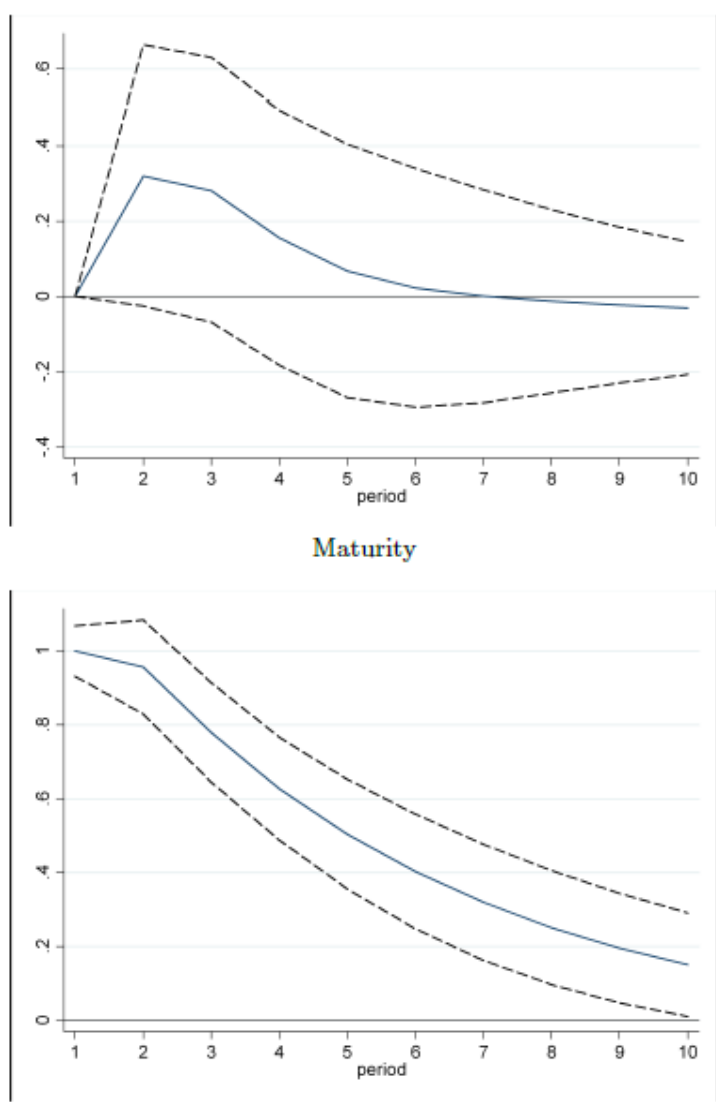

Government Debt

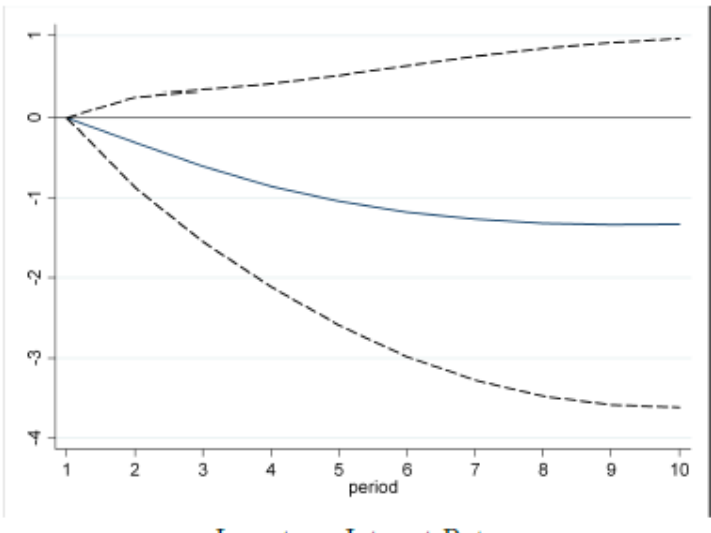

Long-term Interest Rate

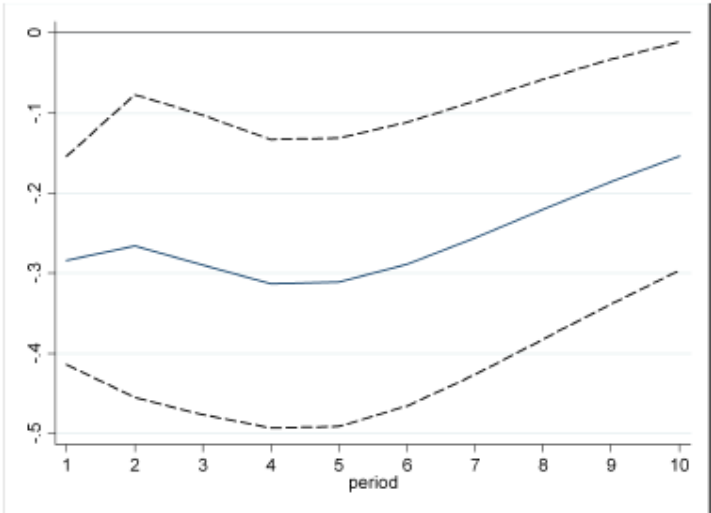

Notes: Dotted lines correspond to \pm 1.645 standard deviations around the central line and are calculated with Monte Carlo simulations.

Figure 2: Response of the long-term interest rate to a one-year maturity increase

Low Inflation Countries

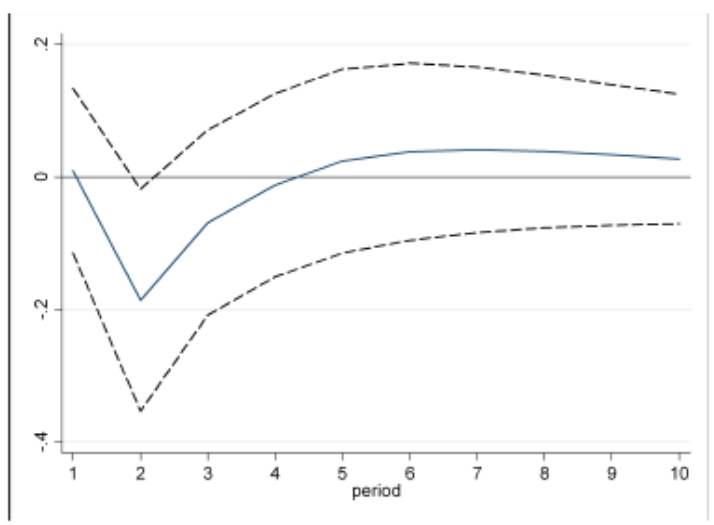

High Inflation Countries

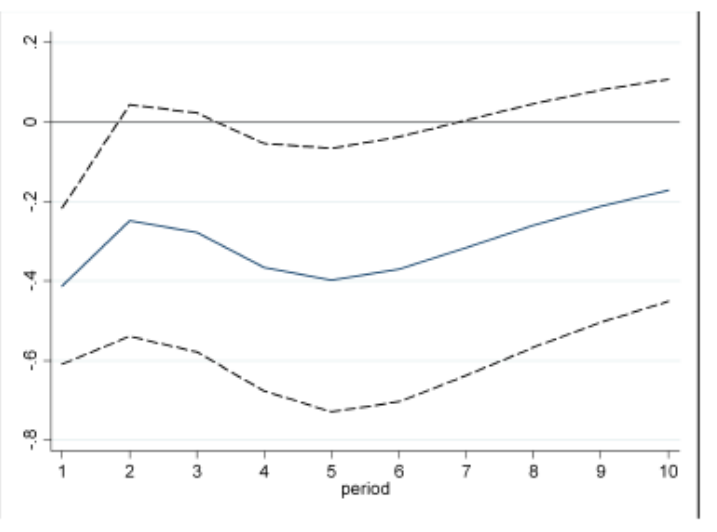



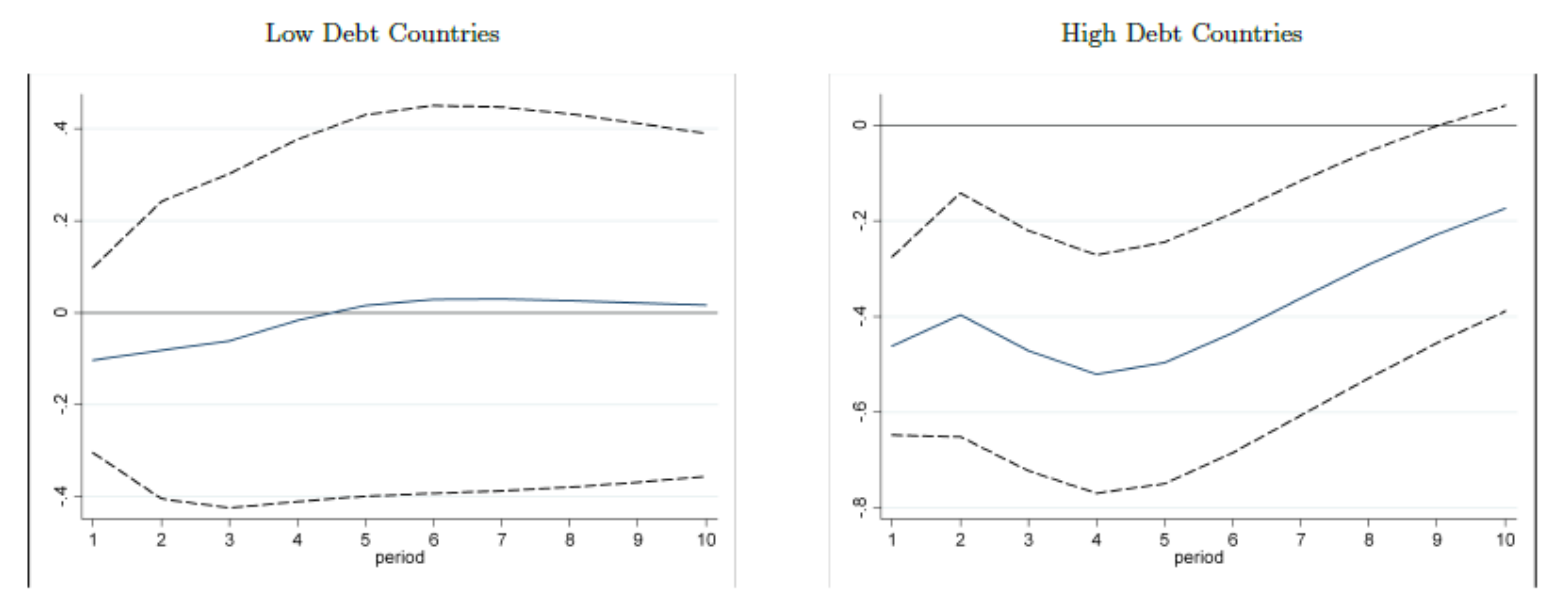

Notes: The two top panels are based on the split into low- and high-inflation countries, while the two bottom panels are based on the split into low- and high-debt countries. Dotted lines correspond to \pm 1.645 standard deviations around the central line and are calculated with Monte Carlo simulations.

\section{Concluding remarks}

Our results suggest that, for a sample of sixteen OECD countries over the period 1980-2007, for given public debt ratio, an increase in the average debt maturity by one year reduces the long-term interest rate on the public debt by around 20-30 basis points. We explore this relationship within both a static panel regression analysis and a panel VAR framework. The effects appear to be stronger for countries with higher average inflation or debt.

\section{References}

Aisen, A. and D. Hauner (2013), Budget Deficits and Interest Rates: a Fresh Perspective, Applied Economics 45, 2501-10.

Ardagna, S., Caselli, F. and T. Lane (2007). Fiscal Discipline and the Cost of Public Debt Service, The B.E. Journal of Macroeconomics 7, 1, 1-35.

Im, K.S., Pesaran, M.H. and Y. Shin (2003). Testing for Unit Roots in Heterogeneous Panels, Journal of Econometrics 115, 53-74.

Missale, A. and O.J. Blanchard (1994), The Debt burden and Debt Maturity, American Economic Review 84, 309-319. 